так і залучення можливостей студентського самоврядування й парламентаризму в розбудові освіти задля сталого розвитку нашої держави. Додатковою аргументацією цього висновку слугують результати анкетування стосовно визначення чинників впливу на формування системи ціннісних екологічних орієнтацій студентів. Вони $€$ неоднозначними: здобувачі предметних спеціальностей «Біологія та здоров'я людини» і «Природничі науки» у цьому процесі надають перевагу освітньому контенту професійної підготовки, тоді як у відповідях майбутніх учителів фізики та хімії прослідковується переважний вплив засобів масової інформації. Спільною закономірністю $€$ незначний вплив громадської природоохоронної роботи, оскільки незначна частка респондентів бере участь у діяльності екологічних рухів, організацій.

Висновки. Таким чином, зважаючи на виявлені відмінності в екологічній підготовці здобувачів вищої освіти за спеціальністю «Середня освіта» відповідних предметних спеціалізацій природничого профілю, для репрезентативності вибірки представництво учасників експерименту має здійснюватися за паритетним принципом, якого необхідно дотримуватися під час формування контрольних і експериментальних груп та на всіх етапах дослідження. Не менш важливим для достовірності проведення педагогічного експерименту $є$ визначення методик психолого-педагогічного діагностування, адекватних обгрунтованій нами структурі, критеріям та рівням сформованості екологічної компетентності майбутніх учителів біології та основ здоров'я, природознавства, фізики та хімії. Дотримання зазначених підходів дасть змогу полегшити узагальнення та інтерпретацію результатів експерименту й обгрунтувати висновки проведеного дослідження.

\section{СПИСОК ВИКОРИСТАНОЇ ЛІТЕРАТУРИ}

1. Гуренкова О. Компонентно-критеріальна структура екологічної компетентності майбутніх фахівців водного транспорту. Освіта дорослих: теорія, досвід, перспективи : збірник наукових праць. Київ, 2011. Вип. 3. Ч. 1. 125-131 с.

2. Ермаков Е. Д. Экологическая концепция формирования экологической компетентности учащихся : автореф. дис. ... д-ра пед. наук : 13.00.01. Москва, 2009. 40 c.

3. Куриленко Н. В. Критеріально-рівневий апарат діагностування сформованості екологічної компетентності учнів основної школи у навчанні фізики. Педагогічні науки : збірник наукових праць. Херсон, 2015. Вип. 67. С. 89-95.

4. Кыверялг А. А. Методы исследования в профессиональной педагогике. Таллинн : Валгус, 1980. 334 с.

5. Лук'янова Л. Б., Гуренкова О. В. Екологічна компетентність майбутніх фахівців : навчально-методичний посібник. Київ; Ніжин : ПП Лисенко, 2008. $243 \mathrm{c}$.

6. Пруцакова О. Л. До проблеми формування екологічної компетентності школярів. Вісник Черкаського університету. Черкаси, 2009. Вип. 162. С. 132-138. (Серія «Педагогічні науки»).

7. Сяська I. О. Структурні компоненти, критерії та рівні сформованості екологічної компетентності майбутніх учителів природничих дисциплін. Науковий часопис НПУ ім. М. П. Драгоманова. Київ, 2019. Вип. 69. С. 255-260. (Серія 5 «Педагогічні науки: реалії та перспективи»).

Дата надходження до редакиії: 24.09.2020 p.
УДК 361.658.4:61-024.75

DOI: $10.37026 / 2520-6427-2020-104-4-101-107$
Наталія ХАРЧЕНКО, кандидат педагогічних наук, дочент кафедри природничо-математичної освіти Рівненського ОІППО

\title{
ВИКОРИСТАННЯ МЕТОДУ ЕКСПЕРТНОГО ОПИТУВАННЯ ПЕДАГОГІЧНИХ ПРАЦІВНИКІВ ЗАКЛАДІВ ЗАГАЛЬНОЇ СЕРЕДНЬОЇ ОСВІТИ В АДВОКАЩЇ̈ ОСНОВ ДОМЕДИЧНОЇ ДОПОМОГИ
}

У статті розглянуто можливість використання одного із методів математичної статистики - експертного опитування - для вдосконалення роботи з питань формування і розвитку в педагогічних прачівників закладів загальної середньої освіти компетениій із домедичної допомоги. Важливу роль при изьому відіграє адвокачія як свідомий спосіб просування актуальних питань збереження життя учасників освітнього процесу. Подано результати практичної діяльності тимчасового науково-дослідницького колективу.

Ключові слова: компетениії із домедичної допомоги, навчання вчителів, практичні навички, метод експертних оцінок, анкетування, адвокація основ домедичної допомоги. 
The article deals with the pedagogical research by the method of expert survey. This allows to identify current problems in the organization of measures for pre-medical aid in educational institutions. This situation has become especially special in recent years, due to the legislative consolidation of the provision of pre-medical aid by teachers. Analysis of the literature shows that the problem is new and there are very few studies on topic.

It has been conducted survey in which took part 447 teachers. The majority of respondents (over 90\%) consciously understand the importance of maintaining the health of participants in the educational process. However, half of the respondents self-assess their knowledge indirectly, have an idea of pre-medical aid at the household or theoretical level. Only one in six can properly provide pre-medical aid. The main sources of new knowledge are mostly the media, social networks and the Internet, and practical skills are acquired sporadically. Only a few teachers are trained. Almost $60 \%$ of respondents gain new knowledge through self-education.

The analysis of the questionnaires allowed to single out the issues of further advocacy of the basics of pre-medical aid. For this purpose, it has been used the method of statistical processing of opinions of B. Gershunsky's experts. The results show that among the selected six factors, the application of the modeling method became the most important; practice and assessment of practical skills; work on clear algorithms.

Preference is given to practical classes and trainings that are complete. Printed sources, lectures and theoretical presentation of the material do not have a significant impact on the formation of teachers' competence in pre-medical aid. And self-education on this important issue is ineffective. This is due to the formation of distorted knowledge, understanding of the problem only at the household level, and in the future - possible wrong decisions in providing assistance.

The proposed advocacy aims to further create a systemic educational program to master the basics of pre-medical aid.

Key words: competence in pre-medical aid, training of teachers, practical skills, method of expert evaluations, questioning, advocacy for pre-medical aid fundamentals.

Постановка проблеми. Своєчасне надання домедичної допомоги постраждалим у критичних для здоров'я ситуаціях є актуальною проблемою сучасної цивілізації, глобальними законами якої життя і здоров'я людини визначені найвищими цінностями. Разом із тим апріорі погіршення ситуації щодо якості здоров'я населення в Україні має кілька причин: від воєнного характеру до способу життя пересічних українців. Хронічні хвороби неінфекційного характеру, надзвичайні ситуації, процеси виробничого характеру, легковажне відношення до небезпек, заходи масового характеру тощо - усе це слугує підгрунтям для акцентування уваги щодо важливості практичних навичок 3 домедичної допомоги. Особливого характеру така ситуація набуває в освітній галузі, де обов'язок педагогічного працівника - уміти надавати домедичну допомогу учасникам освітнього процесу закріплений законодавчо [1].

Протиріччя, викликані неможливістю повною мірою реалізувати практичну сторону проблеми, вказують на потребу ретельного дослідження чинників формування в педагогічних працівників закладів загальної середньої освіти (далі - 33СО) компетенцій із домедичної допомоги, а неоднозначне ставлення в суспільстві до необхідності кваліфікованого надання домедичної допомоги немедичними працівниками та персональної відповідальності дорослих за власні дії вказують на потребу адвокації основ домедичної допомоги.

Аналіз наукових досліджень і публікацій. Загальні проблеми домедичної допомоги постраждалим $є$ предметом уваги вітчизняних і зарубіжних дослідників, зокрема: О. Акулової, П. Волянського, А. Дубицького, I. Кочіна, П. Крилюка, I. Кузьмінського, Т. Пересипкіної, Г. Рощіна, П. Сидоренка, Д. Смайлі, Х. Фарстада, Л. Хофрейтора [4]. Вкрай мало педагогічних досліджень із зазначеного питання (С. Білошицький, Л. Гудзевич, Г. Ількевич, Ю. Скалецький), зокрема наукові джерела, присвячені проблемі формування та розвитку в педагогічних працівників ЗЗСО компетенцій із домедичної допомоги та питанню адвокації основ домедичної допомоги, практично відсутні через нещодавнє оприлюднення на державному рівні (у 2020 році) законодавчих вимог із домедичної допомоги в організації освітнього процесу та відповідних компетенцій педагогів 33СО [7]. У цьому контексті підтримуємо позицію О. Писаревської та розуміємо компетенції як «вміння використати знання, навички, досвід у конкретних умовах, досягнувши при цьому максимально позитивного результату» [6, с. 153].

У нашому дослідженні ми акцентуємо увагу на актуальних питаннях щодо розуміння пріоритетів життя та набуття практичних навичок із домедичної допомоги. Основним компонентом уваги дослідника $\epsilon$ педагогічні працівники 33СО, які мають різні рівні практичних навичок із надання домедичної допомоги і різні потреби у практичному просуванні актуальних питань збереження життя учасників освітнього процесу. Об'єктивні труднощі пов'язані з відсутністю в З3СО системи організації роботи щодо формування та вдосконалення в учителів компетенцій із домедичної допомоги, нерозуміння інструментів адвокації основ домедичної допомоги та відсутність практичних навичок щодо порятунку людей. Це і спонукало нас до виявлення шляхів подолання низького рівня компетенцій із домедичної допомоги у педагогічних працівників 3ЗСО.

Метою статті $\epsilon$ встановлення пріоритетів адвокації основ домедичної допомоги на підставі аналізу результатів опитування педагогічних працівників 3ЗСО та подальшої їх обробки за допомогою методу експертного опитування.

Виклад основного матеріалу. Із метою дослідження чинників браку інформації про методику надання само- та взаємодопомоги у критичних для здоров'я ситуаціях та популяризації базових знань з основ домедичної допомоги як підгрунтя збереження здоров'я та життя учасників освітнього процесу, у 2016 році викладачами кафедри природничо-математичної освіти Рівненського обласного інституту післядипломної педагогічної освіти (далі - РОІППО) було створено тимчасовий науково-дослідний колектив (далі ТНДК) із теми «Базова підтримка життя: модель безпеки людини у сучасному світі». Упродовж останніх п'яти років члени ТНДК досліджували процес формування та розвитку компетенцій із домедичної допомоги у педагогічних працівників 33СО засобами інформування, питання співпраці з громадськими організаціями, опрацювання окремих проблем 
щодо надання допомоги та навчання за програмами спецкурсів із відповідної тематики. Налагодженню системної роботи передували вивчення сучасного стану організації навчань $з$ основ домедичної допомоги, здійснення аналізу законодавчо-нормативної бази, проведення апробації форм навчальної діяльності в системі післядипломної педагогічної освіти.

Для розуміння пріоритетів основ домедичної допомоги було проведене анонімне опитування педагогічних працівників $33 \mathrm{CO}$ із теми «Що ми знаємо з домедичної допомоги». Респондентами стали слухачів курсів підвищення кваліфікації РОІППО та учасники трьох Всеукраїнських конференцій із проблем педагогіки здоров'я. Анкетуванням було охоплено 447 осіб. Констатовано, що показники самооцінки педагогів щодо власних компетенцій із домедичної допомоги відповідають закону нормального математичного розподілу (див. рис. 1): найбільша кількість учасників $(49,2 \%)$ вказують на посередню самооцінку, 25 опитаних $(5,6 \%)$ мають мінімальні знання $з$ основ домедичної допомоги, а 15 (3,4\%) оцінюють свої компетенції максимально.

Оцініть, у якій мірі Ви володієте навичками домедичної допомоги як немедичний

працівник? (1 - $\min . . .5$ - max)

447 відповідей

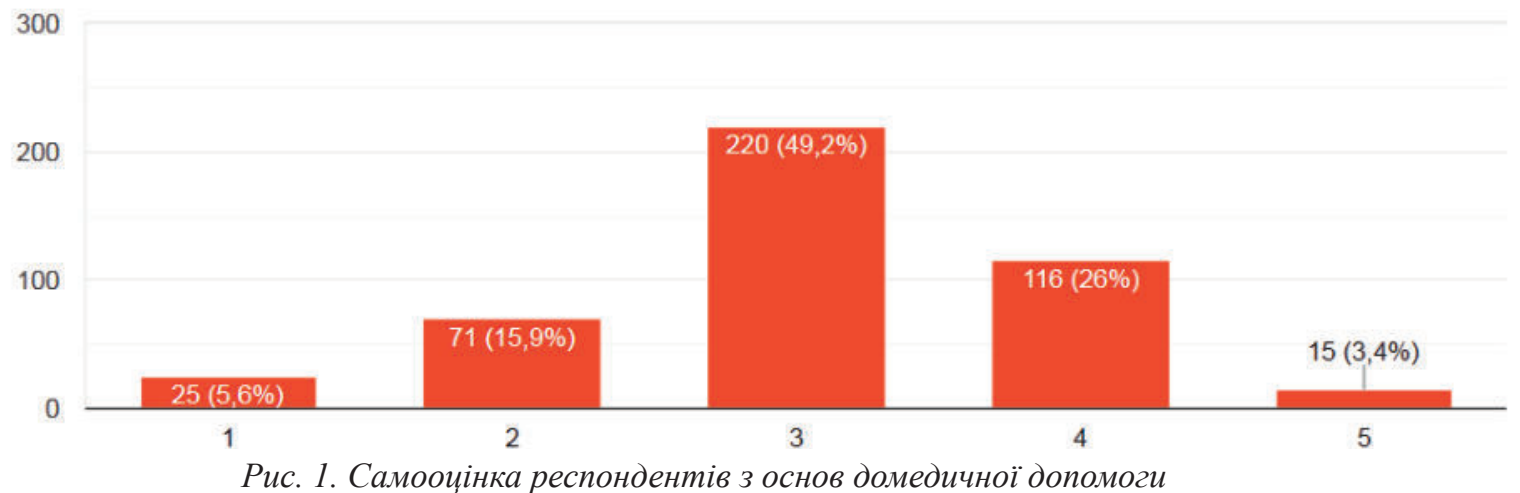

Означені вище дані корелюються 3 відповідями на запитання «Чи надавали Ви допомогу постраждалим до приїзу бригад швидкої допомоги?», де 140 (31,3\%) педагогів вказують на практичні вміння високого та достатнього рівнів, що відповідає максимальному та високому рівням самооцінки. 123 (27,5\%) респонденти ствердно відповіли на запитання, 15 (3,4\%) педагогів виконували вказівки диспетчера швидкої з рятування життя постраждалим, a $2(0,4 \%)$ учасників зізналися, що мали практичний досвід керування організації надання допомоги у критичних для здоров'я ситуаціях.

Якщо на запитання «Чи потрібно дорослим людям оновлювати знання з домедичної допомоги?» та «Хто із педагогічних працівників має володіти навичками надання домедичної допомоги?» ствердно відповіли відповідно 93,1\% (416) та 40,6\% (406) респондентів, то результати опитування щодо запитання «Чи достатня робота з домедичної допомоги проводиться у вашому закладі, установі, організації?» суттєво відрізняються. Зокрема, ствердну відповідь дали лише 188 (42,1\%) респондентів. Крім того, $31,3 \%$ опитаних зазначили, що така робота зазвичай зводиться до власної ініціативи та самоосвіти. На жаль, 20,1\% (90) респондентів дали негативну відповідь, а 3,6\% (16) осіб вказали на відсутність будьяких заходів із домедичної допомоги (див. рис. 2). Звернемо увагу, що результати наших досліджень співзвучні із даними Н. Ількевич, С. Білошицького, Л. Гудзевич [8].

\section{Чи достатня робота з домедичної допомоги проводиться у Вашому закладі/установі} Іорганізації?

447 відповідей
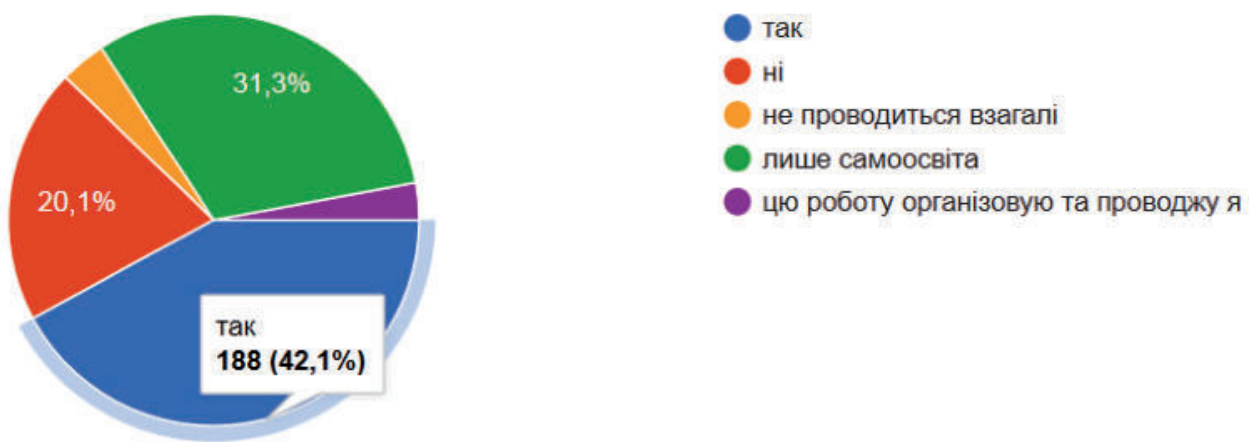

Рис. 2. Організація заходів із домедичної допомоги в ЗЗСО 
Відповіді на представлені нижче запитання взаємодоповнюють одне одного. Вони свідчать про здебільшого побутовий (52,3\%) або теоретичний $(32,9 \%)$ характер знань дорослих. Лише 70 (15,7\%) опитаних на запитання «Якими навичками з надання домедичної допомоги ви володієте?» вказали, що знають і вміють надавати домедичну допомогу за відповідними порядками та алгоритмами дій (див. рис. 3).

\section{Якими навичками з надання домедичної допомоги Ви володієте? (вкажіть кілька} варіантів)

447 відповідей

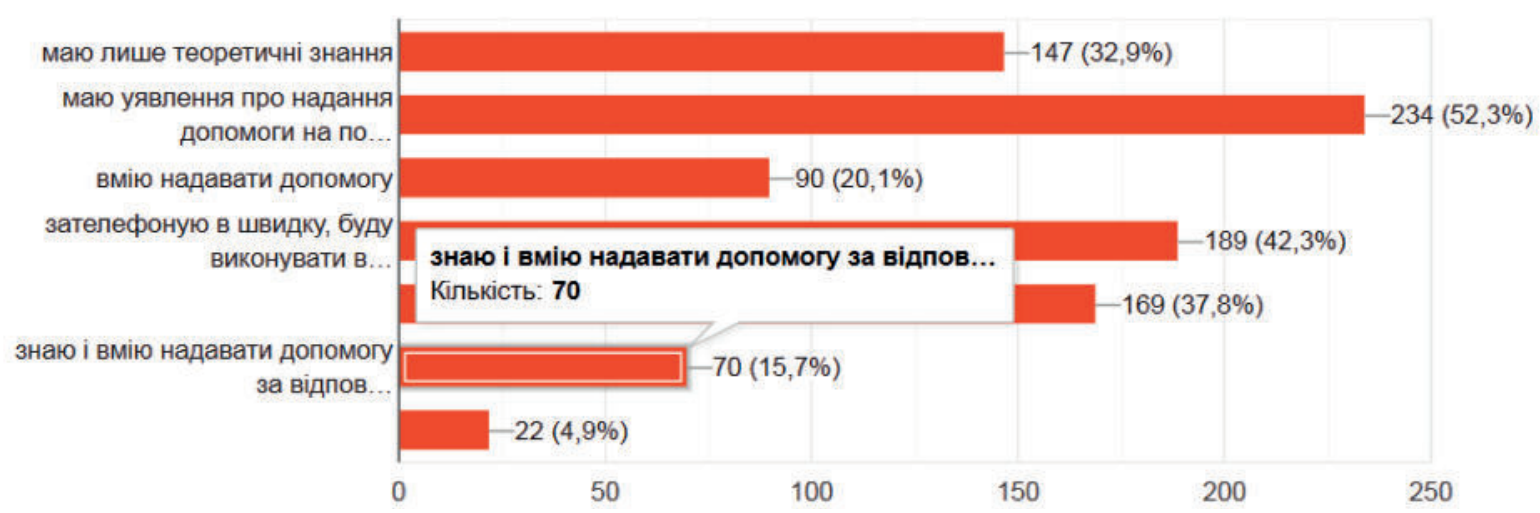

Рис. 3. Компетениії педагогічних працівників із домедичної допомоги

Указуючи джерела набуття компетенцій із домедичної допомоги, педагоги передусім називають мережу Інтернет та соціальні мережі - $269(60,2 \%)$ опитаних; відеоканали - 218 (48,8\%); 3MI - 126 (28,2\%); друкована продукція (бюлетені, газети, журнали, вісники) - 98 (21,9\%). $112(25,1 \%)$ учасників зазначили, що набули компетенцій із домедичної допомоги завдяки тренінгам. Лише 82 (18,3\%) опитаних зауважили, що вдосконалюють свої компетенції завдяки науковим виданням (див. рис. 4).

3 яких джерел Ви найбільше дізналися про домедичну допомогу (відмітьте кілька варіантів)?

447 відповідей

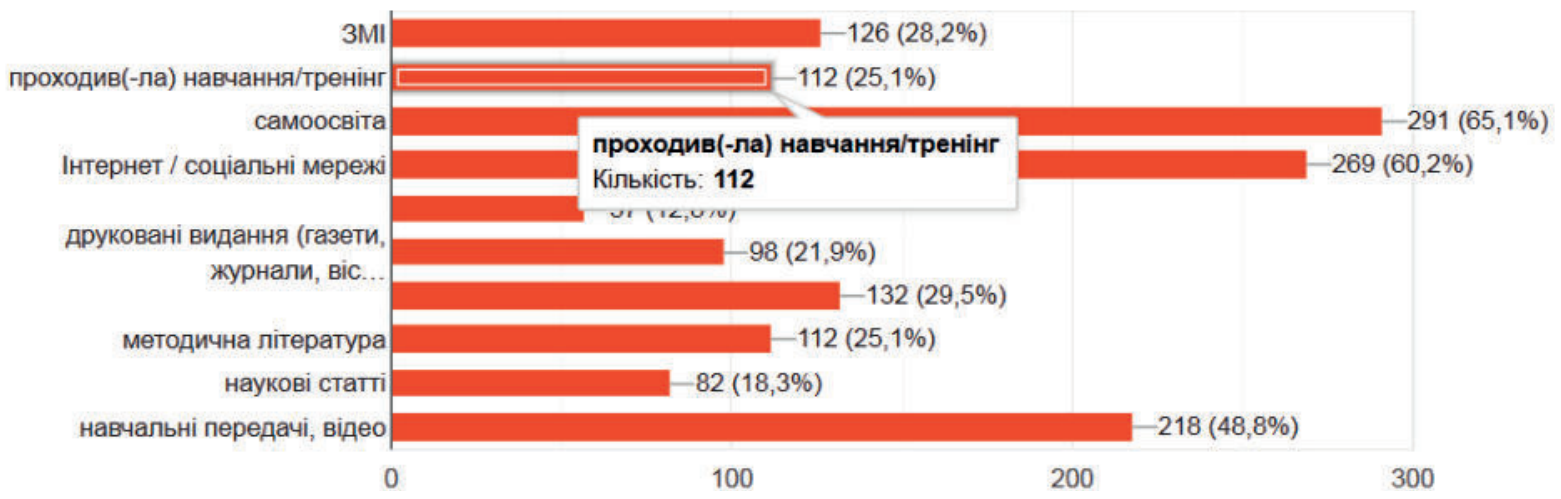

Рис. 4. Джерела формування компетенцій педагогів із домедичної допомоги

Вагомими для дослідження є відповіді респондентів на запитання «На базі яких організаџій ви проходили навчання з домедичної допомоги?». У зв'язку з цим про підвищення кваліфікації засобами професійних курсів на базі закладів МОЗ України вказали 39 (8,7\%) опитаних. 58 (13\%) осіб здобули нові навички упродовж навчання на базі сертифікованих тренінгових центрів громадських організацій. Решта опитаних були задіяні у навчанні епізодичного характеру: на базі ОІППО (87 учасників, 19,5\%); завдяки засобам онлайн-навчання (111 опитаних, $24,8 \%$ ); у ході занять у своїх 33СО (144 респондентів, 32,2\%). Лідером за кількістю відповідей із важливих питань збереження здоров'я та життя учасників освітнього процесу залишається самоосвіта (263 педагоги, 58,8\%) (див. рис. 5).
Таким чином, можемо констатувати, що педагогічні працівники ЗЗСО свідомо розуміють важливість практичної реалізації основ домедичної допомоги в освітньому процесі, однак цим займаються на рівні самоосвіти та епізодично, взявши участь у відповідних заходах. Активізувалася робота закладів освіти із формування та вдосконалення компетенцій педагогів із домедичної допомоги. Беззаперечним $\epsilon$ вплив соціальних мереж на формування уявлень опитаних про домедичну допомогу. Лише кожен шостий зазначає, що вміє і може надати домедичну допомогу за протоколами дій для немедичних працівників.

На основі аналізу анкетування учасниками ТНДК розроблено адвокацію основ домедичної допомоги. 
На базі яких організацій Ви проходили навчання з домедичної допомоги?

447 відповідей

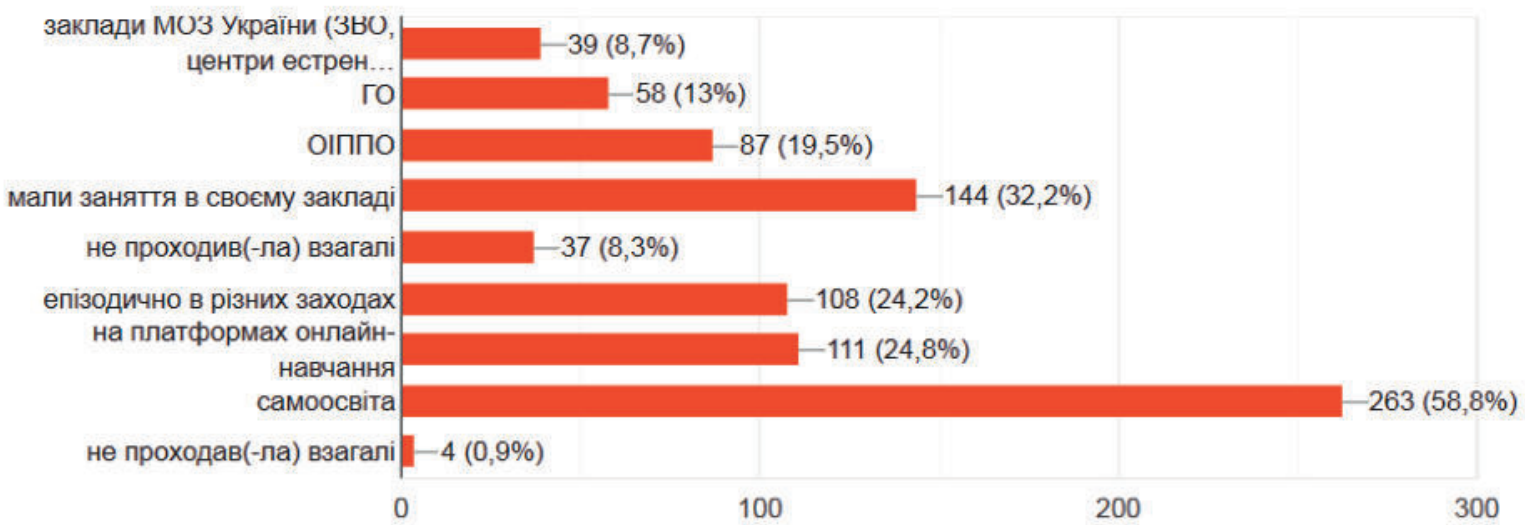

Рис. 5. Способи формування компетениій педагогічних працівників із домедичної допомоги

Що ж варто розуміти під поняттям «адвокація»? Даний термін походить від латинського слова «advocare» і буквально означає «заклик до надання підтримки». Дитячий фонд «Здоров'я через освіту» дає таке його визначення: «Адвокація - просування ідей, що спрямовані на досягнення бажаних змін, ... дії, спрямовані на вирішення суспільно значущої проблеми» [1, с. 8].

Отже, розуміючи проблеми та окресливши пріоритети щодо формування у педагогічних працівників З3СО компетенцій із домедичної допомоги, нами обрано стратегію подальшої роботи. Для встановлення ефективних інструментів адвокації основ домедичної допомоги як свідомого способу просування актуальних питань збереження життя учасників освітнього процесу нами проведено експертне опитування. За основу було обрано методику статистичної обробки думок експертів Б. Гершунського [2; 3, с. 279-291]. На думку А. Киверялга, цей метод у педагогіці відзначається неабиякою надійністю та має значні перспективи у застосуванні [5, с. 118-125].

Експертну групу представляли учасники ТНДК. Обробка матеріалів проводилася із метою виявлення узгодженої думки експертів щодо подальшої організації та вдосконалення навчання слухачів курсів підвищення кваліфікації з основ домедичної допомоги. Результати опитування експертів представлені сукупністю оцінок $C_{i k}$ за десятибальною шкалою. Показником узагальненої думки експертів $є$ середнє арифметичне величини оцінки певного показника (фактора)$\mathrm{M}_{\mathrm{k}}$, яке визначається за формулою:

$$
M_{k}=\frac{1}{m} \sum C_{k} \text {, де: }
$$

$\mathrm{m}$ - кількість експертів, що брали участь в оцінці; $C_{i k}-$ оціночний показник $k$-го фактора $i$-го експерта.

Факторами визначені такі показники адвокації основ домедичної допомоги як свідомого способу просування актуальних питань збереження життя учасників освітнього процесу:

1. Самоосвіта та самостійна робота педагогічних працівників.

2. Відпрацювання навичок дій немедичних працівників за чіткими алгоритмами у критичних для постраждалого ситуаціях, навчальні відео 3 поясненням способів надання домедичної допомоги.

3. Багаторазове повторення (зокрема із контрольними випробуваннями) практичних навичок, моделювання завдань ситуативного характеру.

4. Лекційна подача навчального матеріалу, друкування відповідних методичних матеріалів.

5. Використання методу муляжування у процесі навчання домедичній допомозі.

6. Організація вивчення основ домедичної допомоги окремим навчальним блоком (спецкурс, програма, цикл лекційно-практичних занять).

Результати досліджень та їх емпіричний аналіз лийі 1.

Результати опитування експертів подано в таб-

Таблиия 1

\section{Підсумкова таблиця даних експертного анкетування}

\begin{tabular}{|c|c|c|c|c|c|c|}
\hline \multirow{2}{*}{$\begin{array}{c}\text { oo } \\
\text { фактора }\end{array}$} & \multicolumn{5}{|c|}{ Оцінки експертів ефективності факторів } & \multirow{2}{*}{$\boldsymbol{M}_{\boldsymbol{k}}$} \\
\cline { 2 - 7 } & експерт 1 & експерт 2 & експерт 3 & експерт 4 & експерт 5 & $\mathbf{5}$ \\
\hline 1 & 6 & 5 & 6 & 4 & 7 & $\mathbf{5}, \mathbf{7}$ \\
\hline 2 & 7 & 8 & 7 & 10 & 9 & $\mathbf{9 , 2}$ \\
\hline 3 & 9 & 8 & 10 & 8 & 6 & $\mathbf{6 , 8}$ \\
\hline 4 & 7 & 6 & 7 & 9 & 9 & $\mathbf{9 , 0}$ \\
\hline 5 & 9 & 10 & 8 & 9 & 8 & $\mathbf{7 , 8}$ \\
\hline 6 & 8 & 7 & 7 & & & 7 \\
\hline
\end{tabular}

Сума рангів $\boldsymbol{S}_{\boldsymbol{k}}$ кожного фактора обрахована таким чином:

- таблицю складають бали, виставлені кожним експертом за спаданням вагомості факторів (б);
- проводиться спадне ранжування оцінок за допомогою чисел натурального ряду, які є рангами оцінок певного експерта (ч);

- для оцінок

встановлюються

ранги, 
причому при оцінюванні декількох факторів однаковими оцінками їм присвоюються «зв’язані ранги» (p);

- суми зі стовпців перевіряються контрольним числом за формулою:

$$
S_{m}=\frac{(1+k) \cdot k}{2} \text {, де: }
$$

$k$ - кількість розглянутих факторів;
- далі підраховують суми кожного з рядків $S_{k}$, при цьому фактор, що має найменше числове вираження $S_{k}, \epsilon$ найбільш вагомим;

- важливим моментом $\epsilon$ виконання умови рівності, що виражена формулою $\sum S_{m}=\sum S_{k}$;

- проміжна таблиця у нашому випадку набула такого вигляду (див. табл. 2):

Таблиия 2

Ранжуваня експертних оцінок

\begin{tabular}{|c|c|c|c|c|c|c|c|}
\hline \multirow{2}{*}{$\begin{array}{c}\text { № } \\
\text { фактора }\end{array}$} & \multirow{2}{*}{ Показники } & \multicolumn{5}{|c|}{ Ранжування оцінок експертів ефективності факторів } & \multirow{2}{*}{$S_{k}$} \\
\hline & & експерт 1 & експерт 2 & експерт 3 & експерт 4 & експерт 5 & \\
\hline \multirow{3}{*}{1} & б & 6 & 5 & 6 & 4 & 5 & \multirow{3}{*}{30} \\
\hline & $\mathbf{4}$ & 6 & 6 & 6 & 6 & 6 & \\
\hline & $\mathbf{p}$ & 6 & 6 & 6 & 6 & 6 & \\
\hline \multirow{3}{*}{2} & б & 7 & 8 & 7 & 6 & 7 & \multirow{3}{*}{20} \\
\hline & $\mathbf{Y}$ & 5 & 3 & 5 & 5 & 4 & \\
\hline & $\mathbf{p}$ & 4,5 & 2,5 & 4 & 5 & 4 & \\
\hline \multirow{3}{*}{3} & б & 9 & 8 & 10 & 10 & 9 & \multirow{3}{*}{7,5} \\
\hline & $\mathbf{Y}$ & 1 & 2 & 1 & 1 & 2 & \\
\hline & $\mathbf{p}$ & 1,5 & 2,5 & 1 & 1 & 1,5 & \\
\hline \multirow{3}{*}{4} & б & 7 & 6 & 7 & 8 & 6 & \multirow{3}{*}{22,5} \\
\hline & $\mathbf{Y}$ & 4 & 5 & 4 & 4 & 5 & \\
\hline & $\mathbf{p}$ & 4,5 & 5 & 4 & 4 & 5 & \\
\hline \multirow{3}{*}{5} & б & 9 & 10 & 8 & 9 & 9 & \multirow{3}{*}{8,5} \\
\hline & $\mathbf{Y}$ & 2 & 1 & 2 & 2 & 1 & \\
\hline & $\mathbf{p}$ & 1,5 & 1 & 2 & 2,5 & 1,5 & \\
\hline \multirow{3}{*}{6} & б & 8 & 7 & 7 & 9 & 8 & \multirow{3}{*}{16,5} \\
\hline & $\mathbf{Y}$ & 3 & 4 & 3 & 3 & 3 & \\
\hline & $\mathbf{p}$ & 3 & 4 & 4 & 2,5 & 3 & \\
\hline & & 21 & 21 & 21 & 21 & 21 & 105 \\
\hline
\end{tabular}

Показником ступеня узгодженості експертів є коефіцієнт варіації кожного фактора $V_{k}$. Цей коефіцієнт обчислюється таким чином:

- обраховується дисперсія оцінок $D_{k}$ за формулою:

$$
D_{k}=\frac{1}{m-1} \cdot \sum\left(C_{i k}-M_{k}\right)^{2}, \text { де: }
$$

$m$ - кількість експертів, що взяли участь у оцінюванні;

$C_{i k}$ - оціночний показник $\boldsymbol{k}$-го фактора в $i$-го експерта;
$M_{r}$ - середнє арифметичне величини оцінки факTopa.

- обчислюється середнє квадратичне відхилення оцінок $\sigma_{k}: \quad \sigma_{k}=\sqrt{D_{k}}$;

- знаходиться коефіцієнт варіації $V_{k}$ :

$$
V_{k}=\frac{\sigma_{k}}{M_{k}} ;
$$

- зведена таблиця та остаточні результати думок експертів подано в таблиці 3 .

\begin{tabular}{|c|c|c|c|c|c|c|c|c|c|}
\hline \multirow{2}{*}{$\begin{array}{c}\text { № } \\
\text { фактора }\end{array}$} & \multicolumn{5}{|c|}{$\left(C_{i k}-M_{k}\right)^{2}$} & \multirow{2}{*}{$\sum\left(C_{i k}-M_{k}\right)^{2}$} & \multirow{2}{*}{$D_{k}$} & \multirow[b]{2}{*}{$\sigma_{k}$} & \multirow{2}{*}{$V_{k}$} \\
\hline & 1 & 2 & 3 & 4 & 5 & & & & \\
\hline 1 & 0,64 & 0,04 & 0,64 & 1,44 & 0,04 & 2,8 & 0,7 & 0,8 & 0,15 \\
\hline 2 & 0 & 1 & 0 & 1 & 0 & 2 & 0,5 & 0,7 & 0,10 \\
\hline 3 & 0,04 & 1,44 & 0,64 & 0,64 & 0,04 & 2,8 & 0,7 & 0,8 & 0,08 \\
\hline 4 & 0,04 & 0,64 & 0,04 & 1,44 & 0,64 & 2,8 & 0,7 & 0,8 & 0,12 \\
\hline 5 & 0 & 1 & 1 & 0 & 0 & 2 & 0,5 & 0,7 & 0,07 \\
\hline 6 & 0,04 & 0,64 & 0,64 & 1,44 & 0,04 & 2,8 & 0,7 & 0,8 & 0,10 \\
\hline
\end{tabular}

Таблиия 3

Показники ступеня узгодженості думок експертів

На основі описаної методики нами був проведений аналіз ефективності формування та вдосконалення в педагогічних працівників $33 \mathrm{CO}$ компетенцій із домедичної допомоги.

Найбільшого прогностичного значення набув п’ятий фактор. Отже, узгоджена думка експертів вказує на першочерговість використання навчальних манекенів, обладнання та засобів надання допомоги (методу муляжування). Вагомого значення у формуванні домедичних компетенцій педагогів має моделювання ситуацій та багаторазове повторення практичних навичок із відповідним оцінюванням набутих умінь (фактор № 3). Достатніми є системна навчальна робота за чіткими алгоритмами дій із надання допомоги (відповідно фактори № 2 і № 6). Викладання лише теоретичного матеріалу та розробка 
друкованих вказівок (фактор № 4) не має суттєвого впливу на вдосконалення відповідних компетенцій, а самоосвіта (фактор № 1) є неефективною у формуванні та розвитку в педагогів компетенцій із домедичної допомоги.

Висновки. Аналіз результатів опитування педагогів 3 актуальних питань домедичної допомоги та проведене експертне оцінювання вказують, що в системі післядипломної освіти адвокацію з основ домедичної допомоги мають складати оцінювані системні заходи практичного характеру із застосуванням навчального обладнання, наприклад, цикл тренінгів чи завершена освітня програма. Неефективність самоосвіти підтверджена результатами анкетування: знання формуються на побутовому рівні, можливі спотворені уявлення про способи надання допомоги та помилкові рішення.

Перспективи подальших досліджень. Результати проведеної роботи дозволили укласти освітню програму за тематичним напрямом «Створення безпечного освітнього середовища та основи надання домедичної допомоги», яку плануємо апробувати у Рівненському ОІППО у 2021 році.

\section{СПИСОК ВИКОРИСТАНОЇ ЛІТЕРАТУРИ}

1. Адвокація в профілактичній освіті : посібник для активістів неурядових організацій / О. Березюк, К. Візін, Т. Воронцова та ін. Київ : Здоров'я через освіту, 2014. 64 с.
2. Васильев И. Б. Теоретические и методические основы подготовки педагогов профессионального обучения : монография. Харків : Смугаста типографія, 2014. 397 с.

3. Гершунский Б. С. Образовательно-педагогическая прогностика. Теория. Методология. Практика : учебное пособие. Москва : Флинта, 2003. 768 с.

4. Екстрена медична допомога (догоспітальні протоколи) / О. В. Богомолець, Г. Г. Рощін, С. В. Синельник та ін. ; за ред. О. В. Богомолець, Г. Г. Рощіна. Київ : Юстон, 2016. 211 с.

5. Кыверялг А. А. Методы исследования в профессиональной педагогике. Таллинн : Валгус, 1980. $335 \mathrm{c}$.

6. Писаревська О. В. Методологічні аспекти формування стратегічної компетентності майбутніх юристів в університетах Франції. Молодь і ринок. Дрогобич, 2019. Вип. 6 (173). С. 152-158.

7. Про повну загальну середню освіту : Закон України від 16 січ. 2020 p. URL: https://zakon. rada.gov.ua/laws/show/463-20\#Text (дата звернення: 30.09.2020).

8. Харченко Н. Правові засади формування компетенцій із домедичної допомоги в педагогічних працівників закладів загальної середньої освіти. Нова педагогічна думка. Рівне : РОІППО, 2020. № 3 (103). C. 153-158.

Дата надходження до редакиіï: 16.10.2020 p. 